\title{
Geotourism Resources as Part of Sustainable Development in Geopark Indonesia
}

\author{
Ayu Krishna Yuliawati \\ Management Study Program \\ Universitas Pendidikan Indonesia \\ Bandung, Indonesia \\ ayukrishna@upi.edu
}

\author{
Krishna Nur Pribadi \\ Institute Teknologi dan Sains \\ Bandung Bekasi, Indonesia
}

\author{
Mohamad Sapari Dwi Hadian \\ Environmental Geology Faculty of \\ Geology Universitas Padjadjaran \\ Jatinangor, Indonesia
}

\begin{abstract}
Indonesia is known as rich in natural resources due to its location in the ring of fire and meeting of three continental plates. There are two international geopark recognized by Global Geopark Network UNESCO, which are Batur Global Geopark dan Sewu Global Geopark. The geopark contains Indonesia's geotourism resources explored in this study through the perception of management. Competition for geotourism destination to attract tourists is high, since other neighboring countries also have offered geotourism. The objective of this study is to explore the geotourism resources in geopark, and how it is linked to sustainable development. Research utilize qualitative method, collecting secondary data and primary data through interview guided with semi-structured questionnaires with two geopark management organization about 10 geopark personnel and 100 tourists. The results found that respondents have perceived geotourism resources in the geopark to be rich and diversified, but lack in conservation, interpretation, resources management and needs further development based on the sustainability principle. Recommendation is suggested to the stakeholder such as geopark management, government, community, and academics for more coordination and collaboration to ensure geotourism resources play a role in sustainable development.
\end{abstract}

Keywords- Geotourism resources, sustainable development, geopark

\section{INTRODUCTION}

Indonesia is a country rich with natural and cultural resources, which have the potential to be developed further the tourism sector. Located in the ring of fire, Indonesia has unique geological features, these geological areas that contained geodiversity and biodiversity. The geological area is one of the important heritage, it contains the history of mankind in the area. Geology is important as part of the natural systems. Understanding of climate, landforms and biodiversity depends on geological studies. Even human habitation and cultural heritage depend on geology. The concept of geoconservation and preservation of geological heritage has appeared only recently (Wilson 1994; Sharples 1997; Osborne 2000,Brilhá 2002) Many efforts have been made for the protection of biodiversity, yet initiatives towards the conservation of geodiversity are often neglected. There are 3 world heritages and 50 national parks in Indonesia that existed on geological bases and have geological meanings.
The development of the areas where geosites lay, not all practice the sustainable development approach in the field.

Sustainability has been defined as the consumption of goods and services that meet basic needs and quality of life without jeopardizing the needs of future generations[1]. Based on UNWTO [2] data, in 1950 the number of visits counted as many as 25 million people, in 1980 reached 278 million people, then in 1995 increased to 528 million people, and in 2014 increased again to 1.138 million people. So it can be said that the tourism industry is one of the economic sectors with the largest and fastest growing in the world. The rising number of tourist in geosites could jeopardize the sustainability of the area.

The geosites are located in the geopark, defined as a territory with a particular geological heritage of international appeal, which is developed. One of the destinations visited by many tourists is a geotourism destination. It is tourism based on the earth's natural objects such as mountains, rivers, valleys, beaches, waterfall, lakes, rocks and so on. Indonesia has a lot of potential. Geotourism located at geopark scattered throughout the region, but has not been developed. Until now, Indonesia has only one global geopark region namely Batur Global Geopark. Indonesia is still less competitive than China in 2012 already has about 140 national geopark and 28 of them including the UNESCO global geopark network [3]. China have linked its geopark netwrok with scholarly research on this filed, while in indonesia there has only been few research conducted in the Indonesian geopark. Research in this field is one of the prequisite for applying the status on international geopark.

There have been a limited amount of study in geotourism compared to other types of tourism because it is a new concept. Studies done by Burne and Chapple [4], and Hose [5] shows the negative effect of tourism on geosites due to mass tourism.

Several research conducted by $\mathrm{Li}[6]$, Teh and Cabanban [7] dan Jacob [8] have taken into consideration the indicators for sustainable tourism development in tourism destinations in order to consistently apply the sustainable development principle. Geotourism approach can be adopted where the main elements are: sustainability, conservation, benefiting the community and appreciation of the cultural and geoheritage value through education and interpretation [9]. 
Geopark is integrated with geological heritage area that used to promote the development of local communities in a sustainable manner. Low environment sustainability to be one of the factors that cause travelers less inclined to come back to geo destinations in Indonesia. There are seven geoparks in Indonesia, two with International recognition: Batur Global Geopark and Sewu Global Geopark. This research objective is to explore the geotourism resources in geoparks, and how it is linked to sustainable development.

\section{LITERATURE REVIEW}

Geotourism is considered a feasible tactic to stimulate economic activities and sustainable development in geoparks, Although the launching of geoparks and geotourism is still in the early stages [10]. A geopark must meet the following requirements, such as: must have at least one national and international geodiversity geoheritage, be developed by conservation-based management and educational activities based on sustainable development for the welfare of society. Geotourism have benefit for the local community supporting conservation principles related to natural resources, culture, heritage and traditions. Geotourism benefits the local community and not only celebrates sense of place, but also supports principles of conservation related to natural resources, culture, heritage and traditions [11]. Geopark as a geotourism destination is closely linked to sustainable development. The strategy for regional sustainable economic and cultural development is to integrate the preservation of geological heritage [12]. In line with this, a study described the important role of a geopark in development of geotourism and local economy in rural areas [13]. Geotourism in geopark create innovative local enterprises and generate new source of income. Geopark also play a role in reviving the local culture [12].

An important contribution to the local economy instantiated by the presence of the museum is the increasing number of scientific congresses and meetings organized in the Museum c hall. These events bring scientists from all over the world to the geopark, helping the geopark become well known in the academic community as well as to promote the existing infrastructure for the hosting of academic and educational activities (i.e. research groups, educational visits, students field work). As a result, several universities have started to organise student visits and field work in the geopark [14].

Some research were done in geotourism in Indonesia is conducted in the Pemuteran area and Ciletuh geopark. The biodiversity of Pemuteran had been declining rapidly before the Biorock reef restoration projects were installed. Lessons learnt from the Pemuteran success in using biorock to restore coral reefs and the tourism and fisheries as the backbone of the coastal economy as well as restoring the geo-biodiversity baseline could be applied at Halong. One of the Biorock method's key successes is the acceptance, engagement and support from local community in preserving their biogeodiversity [15].

Several research conducted in the geopark Cilteuh area about geodiversity in the area is conducted by scientists on the characteristic uniqueness of Ciletuh, Sukabumi area and its' implications [16], and on the Geology of Ciletuh Geopark [17].

\section{METHODOLOGY}

Geotourism is an emerging geoscience with clear and deep social interrelation, which must be grounded in knowledge and methods developed in different sciences, thus approaching the social sciences of the natural sciences. Such holistic vision must be taken into account not only in its scope, but also in its methods, including in multi discipline research procedures. Data collection is done to collect resources in research either in the form of secondary data and primary. Secondary data were obtained through geopark reports, borchures and literature review. While primary data obtained through semistructured interviews and observation on the object under study. Interviews were conducted with geopark management ins two International Geopark management consisted of a geological agency program manager, community representatives, and academics who have knowledge on management and geology. Out of the population for 7 geoparks, only 2 international geoparks in Indonesia that become the sampling unit. About 10 personnel from the management of two geoparks were interviewd and questionairre to 100 tourists were given. The study utilize nonprobability purposive sampling technique for the sample selection and is based on calculated personal judgments, and researchers utilize their own perceptions and knowledge to determine the sample size.Within the sample design, purposive sampling technique was used to collect the primary data from the respondents [18].

In conducting the data analysis used qualitative content analysis method and descriptive analysis. This analysis is used as a method in the study due to consider the shape of the data and information collected in the form of interviews, survey and official documents that require techniques to understand and interpret the data. Descriptive methods that are used this time is analytic description. Analytic description is a description that is done by connecting the data that has been obtained by categories on existing theory so as to produce a new description.

\section{FINDINGS AND DISCUSSION}

Indonesia is rich in diversity of geology as a result of geological processes over millions of years ago. The formation of volcanic landforms exposure (quarter and ancient) in Java and Bali island as part of the Ring of Fire. The beauty of the south coast of West Java as a result of tectonic processes that developed makes this area will have trace the formation of the earth that is worth of high science and landscapes beautiful and exotic as a national tourism potential. Geopark as areas that have tourism potential of geo not immune from threats to the environment when not managed properly tourist objects. The management in Batur and Sewu global geopark said that the area choose to became a geopark, because it can derives economic value thus causing local economic development through tourism activities. Local economic development through nature-based tourism 
activities. Geotourism is part of sustainable development in the area. Developing geopark tourism activities in a sustainable manner is defined as the activities and efforts of balancing between economic developments and nature conservation.

Activities that can be done in the Batur and Sewu global geopark include: hiking/trekking, mountain bike cycling, swimming in the beach, caving, sightseeing, bird watching, canoe, rafting, tubing in caves and other adventure-naturebased activities. Geotourism resources in the geopark consists of natural resources and human resources. Tourism is growing in Batur and Sewu geopark, selling beauty of the landscape, but the management has not given education aspect of geopark to the visitors and general public. Education about the geological history and culture as a system resulted in the beauty of the Geopark area landscape. Therefore, without knowledge on the area, this cause lack of public awareness and visitors efforts to conserve in the region.

TABLE I. Key Findings In GeOTOURISM ResourCES AT SEWU GLOBAL GEOPARK

\begin{tabular}{|c|c|}
\hline Sewu Geop & \\
\hline $\begin{array}{l}\text { Geotourism } \\
\text { Activities }\end{array}$ & $\begin{array}{l}\text { Cave exploration and body rafting can be done } \\
\text { following the river inside the cave. Length of the } \\
\text { caving path is about } 700 \mathrm{~m} \text { ). Trekking to the } \\
\text { waterfall and mountain areas, sightseeing, and } \\
\text { birdwatching. }\end{array}$ \\
\hline Natural & The caves in Sewu thrive on limestone cave \\
\hline Resources & $\begin{array}{l}\text { Oyo formations produced about } 1.8 \text { million } \\
\text { years ago. Steep cliffs in the cave is the } \\
\text { escarpment fault. Various sizes of stalactites } \\
\text { and flowstone adorn the cave paths. Their } \\
\text { conservation efforts are paying attention } \\
\text { geosites sustainable development principles. } \\
\text { Geoheritage conversation are conducted by } \\
\text { the relevant institutions in the area. }\end{array}$ \\
\hline
\end{tabular}

\begin{tabular}{ll}
$\begin{array}{l}\text { Human } \\
\text { Resources }\end{array}$ & $\begin{array}{l}\text { Human resources, managerial knowledge } \\
\text { about the management of geopark is limited. } \\
\text { Geopark management has not been well } \\
\text { integrated in terms of resource management } \\
\text { between agencies. }\end{array}$ \\
\hline
\end{tabular}

One of the main function of Geopark other than recreation and conservation, it has the function for public education. In terms of education, geopark should be able to increase the understanding of the earth and all the processes that occur therein for the surrounding communities and the wider society. Tourists and visitors of the park is a currently growing niche market that carefully consider the environment and take into account issues such as: purity of nature, educational tourism, culture and history, large- and small-scale events, and entertainment and fun. These values and needs may be satisfied by implementation of geotourismin the geopark area.
TABLE II. KEY FINDINGS IN GEOTOURISM RESOURCES AT BATUR GLOBAL GEOPARK

\section{Batur Geopark}

\begin{tabular}{ll}
\hline Geotourism & Batur Summit Geotrails is the path to substantive \\
Activities & volcanic peaks and several craters through \\
& walking. This trip was accompanied by a tour \\
& guide who was appointed by the Geopark Batur, \\
& in particular the guide of an observation center \\
& Volcanology. Trails for mountain bike is \\
& prepared at the foothills of the volcano and \\
& consisted of frozen lava.
\end{tabular}

Natural Caldera landscape evolution, Strombolian type Resources eruption, lava flow. Mount Batur has a caldera measuring $13.8 \times 10 \mathrm{~km}$, and is one of the largest and most beautiful in the world. There Batur caldera geological formation consisting of geological formations Batur volcano rocks containing agglomerates, lavas and tuffs. Batur has a variety of types of lava comprehensive in the world in the body of the mountain. Dividing zone mining area and geopark region so that the path of mining and travel lanes are planned to be separate. Water conservation is done by keeping the lake Batur as areas protected by customary law and is not allowed by the religious leaders and community leaders to do exploration. For geoconservation purposes a booklet was published to increase the park visitior knowledge about the natural environment.

Human Interpretation of the geosites is key issue for Resources visitors. The park management have acknowleged this issue and training guide for local residents conducted by the ministry of tourism in collaboration premises Ministry of Energy and the local tourism agency.

Exploiting natural kind of tourism sites and landscapes containing earth-science interesting features in a didactic and entertaining way, relative to demand, a form of tourism based on imagination and emotion, favoring experience and sensations, and explaining the natural environment by playing with its temporal and spatial dimensions may provide opportunities of economic development. For instance, a mix of walking, wellness, "agro-tourism" and "Geotourism" may be profitable for regional economic development.

The concept of tourism that developed in the area, has not shown the value of togetherness "Share Value" among stakeholders so that development programs are run in an area not well integrated. Efforts are being made still limited, moreover, people around who have not fully involved in a tourism development (community still become the object of a system of tourism) makes inhibition of the development program will be a tourist destination, because not a few tourist area that displays the geological phenomenon to be not optimal due to the conflict of interest between stakeholders. Both of these have an impact on maximizing the local revenue from tourism. The natural beauty, culture, and the biodiversity 
that Batur Global Geopark dan Sewu Global Geopark has significant value and the potential, especially in increasing local and regional economic growth.

\section{CONCLUSIONS}

Geotourism has great potential in Indonesia, because the country has great geodiversity which spread across the country, some places need to be made as geoheritage region. Due to the recent development of the concept in Batur and Sewu global geopark some gap about the conservation of practices occur hindering sustainable development. Ther strategy to conserve natural resources is associated with geotourism. It is found in Batur and Sewu global geopark that within geotourism based, education for tourists is key in sustainable development of the area. In particular, it is necessary for management of the geopark to give their considerations for the geological conditions, human resources through geoeducation program that include materials on geodiversity. Management must collaborate more with key stakeholder of the geopark such as academics, business and media.

\section{ACKNOWLEDGMENT}

Special thanks is given to the team member of this article, Prof. Didi Sukmayadi, Vice Rector IV Universitas Pendidikan Indonesia, Prof Agus Rahayu and Prof Ratih Hurriyati from the School of Post-Graduate Study Universitas Pendidikan Indonesia, Dean of Economics Education and Business Universitas Pendidikan Indonesia, Vijaya Isnaniawardhani Dean of Geology Faculty Padjadjaran University, Dean of Graduate School Prof. Hendarmawan, Padjadjaran University, for their support in this article so that it can be completed and submitted in this conference.

\section{REFERENCES}

[1] Murphy M, editor. The OECD small and medium enterprise outlook. OECD Publishing; 2002.

[2] UNWTO TO. Tourism Highlights, 2014 edition. World. 2014.

[3] Wang, Guangyu, et al. National park development in China: conservation or commercialization?. Ambio, 2012, 41.3: 247-261.

[4] Burne, R., \& Chapple, R.. Under the boardwalk-Tourism's encounters with stromatolites. Addressing the issues of stromatolite protection and visitor management. In Inaugural Global Geotourism Conference Australia ((2008)pp. 107-112).

[5] Hose, T. A. Editorial: geotourism and geoconservation. Geoheritage, 2012, 4(1), 1-5.

[6] Li, Y.. Exploring community tourism in China: The case of Nanshan cultural tourism zone. Journal of Sustainable Tourism, 12(3),(2004,175193.

[7] Teh, L., \& Cabanban, A. S. Planning for sustainable tourism in southern Pulau Banggi: an assessment of biophysical conditions and their implications for future tourism development. Journal Of Environmental Management, 2007,85(4), 999-1008.

[8] Jacob, S. Understanding Culturally Sustainable Tourism: An Observed Comparison of the Models Followed by Kerala and Goa. In Proceedings of Conference on Tourism in India-Challenges Ahead, IIMK. 2008, May.

[9] Dowling, R. K.. The emergence of geotourism and geoparks. Journal of Tourism, 2008,9(2), 227-236.

[10] Torabi Farsani, N., Coelho, C., \& Costa, C. Geotourism and geoparks as gateways to socio-cultural sustainability in Qeshm Rural Areas, Iran. Asia Pacific Journal of Tourism Research, 2012. 17(1), 30-48.

[11] Miller, R. K., \& Washington, K. Geotourism, travel \& tourism market research handbook. Ireland: Key Note Publications Ltd. 2009. chap. 22, pp. $170-172$

[12] Eder, W. Geoparks-promotion of earth sciences through geoheritage conservation, education and tourism. Geological Society of India, 2008,72(2), 149-154.

[13] Farsani, T. N., Coelho, C. E. L. E. S. T. E., \& Costa, C. Geoparks As Art Museums For Geotourists. Journal of Tourism and Development, 2010. 2(13/14), 567-576.

[14] Zouros N. The European Geoparks Network: Geological heritage protection and local development-A tool for geotourism development in Europe. In4th European geoparks meeting 2006,pp. 15-24.

[15] Ontosari ,David, Prawita Tasya Karissa, Medianto Tjatur, Hamzah Lating Rushelan Sudharna4, Komang Astika, I Made Gunaksa5, Thomas J. Goreau, Geotourism combining Geo-Biodiversity and Sustainable Development of Tropical Holocene Coral Reef Ecosystems: Comparison of Two Indonesia Eco-regions using Biorock Technology PROCEEDINGS Joint Convention Balikpapan 2015 HAGI-IAGIIAFMI-IATMI 5-8 October 2015.

[16] Rosana, Mega F. Undang Mardiana, Ildrem Syafri, Nana Sulaksana dan Iyan Haryanto, Geologi Kawasan Geopark, Sukabumi : Karakteristik, Keunikan dan Implikasinya, Lokakarya Penelitian Unggulan dan Pengembangan Program Pascasarjana FMIPA UNPAD 3 April 2006.

[17] Rosana, Mega F. Geologi_Kawasan_Geopark Sukabumi, Bulletin Scientific Contrubution, Vol.6 no 2 tahun 2008, Perencanan Wilayah dan Kota A SAPPK Vol 3 No. 1 tahun 2013 hal 77-86

[18] Bhuiyan MA, Siwar C, Ismail SM. Sustainability Measurement for Ecotourism Destination in Malaysia: A Study on Lake Kenyir, Terengganu. Social Indicators Research. 2015,pp:1-7. 